\title{
Michel Baron, Le Rendez-vous des Tuileries ou Le Coquet trompé
}

\section{Monica Pavesio}

\section{Q OpenEdition}

1 Journals

\section{Edizione digitale}

URL: http://journals.openedition.org/studifrancesi/1329

DOI: 10.4000/studifrancesi. 1329

ISSN: 2421-5856

\section{Editore}

Rosenberg \& Sellier

\section{Edizione cartacea}

Data di pubblicazione: 1 décembre 2015

Paginazione: 590

ISSN: 0039-2944

\section{Notizia bibliografica digitale}

Monica Pavesio, «Michel Baron, Le Rendez-vous des Tuileries ou Le Coquet trompé», Studi Francesi

[Online], 177 (LIX | III) | 2015, online dal 01 décembre 2015, consultato il 09 janvier 2021. URL: http:// journals.openedition.org/studifrancesi/1329; DOI: https://doi.org/10.4000/studifrancesi.1329

Questo documento è stato generato automaticamente il 9 janvier 2021.

\section{(c) $(1) \&$}

Studi Francesi è distribuita con Licenza Creative Commons Attribuzione - Non commerciale - Non opere derivate 4.0 Internazionale. 


\title{
Michel Baron, Le Rendez-vous des Tuileries ou Le Coquet trompé
}

\author{
Monica Pavesio
}

\section{NOTIZIA}

MICHEL BARON, Le Rendez-vous des Tuileries ou Le Coquet trompé, Édition présentée, établie et annotée par J. M. HOSTIOU, avec la collaboration de C. MONNIER, London, The Modern Humanities Research Association, 2013, pp. 151.

1 Creata nel 1685 e rappresentata alla Comédie-Française, con le musiche di Marc Antoine Charpentier, Le Rendez-vous des Tuileries è la prima pièce teatrale di Michel Baron, allievo di Molière e attore di grande successo alla fine del XVII secolo. L'edizione della commedia, in tre atti e in prosa, preceduta da un prologo drammatico, nasce dalla collaborazione tra J. M. Hostiou e la musicologa C. Monnier. Insieme hanno ricostruito quest'interessante commedia, in cui Baron s'inserisce nella scia del suo maestro Molière, proponendosi di rinnovare la commedia classica con un'estetica nuova. L'editore approfondisce, nell'introduzione, le principali caratteristiche di questa commedia notturna, che tratteggia con cinismo una società decadente fin-de-règne $\mathrm{e}$ mette in crisi i valori assoluti dell'Ancien Régime. Si sofferma sul prologo drammatico, il più lungo nella storia del teatro francese fino alla fine del xvIII secolo, e sull'intertestualità di una pièce, che riprende, a volte letteralmente, intere scene dell'Impromptu de Versailles di Molière. Molto interessanti sono anche gli annessi musicali, contenenti la ricostruzione delle partiture musicali che Charpentier scrisse per questa commedia, spesso parodiando alcune delle arie più famose di Lully. L'edizione critica, completata da un'esaustiva bibliografia, contribuisce alla riscoperta di una delle numerose creazioni drammatiche della fine del xvII secolo, purtroppo, completamente oscurate dalla fama delle opere di Molière. 